\title{
IMPACT OF PERCEIVED RISK ON CUSTOMER'S ONLINE PURCHASE INTENTION TOWARDS BRANDED APPARELS
}

\author{
Wajiha Iqbal ${ }^{1}$
}

\begin{abstract}
The purpose of the current research is to assess the influence of perceived risk on online purchase intention of customers towards branded apparels. For discussing perceived risk, it has made use of five different factors which are product risk, time risk, social risk, security risk, and financial risk. It has evaluated the impact of these risks on online purchase intention. For collecting data, survey has been used as the method and quantitative analysis used for testing hypothesis established. Data was collected from 20 respondents who participated in the survey online and the collected data was analyzed by using IBM SPSS Statistics 25. The findings suggest that there is influence of perceived risk on consumers when they are purchasing branded apparels online. Two factors product and financial risk have significant and negative influence on customers online purchase intention. However, other factors which are security, social, and time risk are insignificant. In the context of practical implication, this study would be helpful for online retailers and would provide them an overview of the customer's perspective regarding the risks that restricts them from purchasing branded apparels online.
\end{abstract}

Keywords: Online Shopping, Online Purchase Intention, Perceived Risk, E-Commerce, Risk in Online Shopping, Online Consumer Behavior.

\section{INTRODUCTION}

The internet growth has resulted in an increase of online shopping due to which it is third in the list of most popular activity which is followed by instant messaging and web browsing. Online shopping is the facility that has allowed people to purchase products online making it a flexible

\footnotetext{
${ }^{1}$ Institute of Business Management, Karachi, Pakistan
} 
means buying. Consumers prefer online shopping because it has become an efficient means for business and communication (Kamalul Ariffin et al., 2018). It has been identified by the Internet World Stats that in 2017 there were more than 4 billion internet users it indicates $577 \%$ growth since 2000. As per current statistics shared by them, the total internet usage growth has been by $1167 \%$ from which majority internet users are in Asia forming 50.4\% of the total (Internet World Stats, 2020). The Asian regions conquer the internet usage with highest internet usage along with penetration rate of $53.6 \%$. However, the penetration rate of Europe is highest that is $87.2 \%$ while the internet percentage of the region is only 15.9\% (Internet World Stats, 2020).

The global ecommerce sales from 2016 to 2019 have shown significant growth from \$2 in 2016 to $\$ 3.46$ in 2019 (Young, 2019). This indicates the fact that online shopping is being preferred by people around the global and they are using internet as the means to purchase products. It shows that due to internet the business has revolutionized to online shopping. Due to availability of internet access on various devices such as mobile phones, computers, tablets, and laptops at different places such as office, public places, and others, the trend of online shopping has become a significant transaction mode. It is now becoming part of daily life ranging from purchase of apparels, beauty products, flight tickets, hotel bookings, and others towards online grocery. It is noticed that from the products purchased by consumers online travel related products are on the top followed by general consumer goods and books.

Even though the electronic commerce and online shopping is increasing, it also giving rise to some challenges and problems that impact its process. The concerns that are important for the internet users are data protection, payment security, insufficient information, validity of contract, product quality, and others. In comparison to traditional retail, the consumers shopping online tend to perceive higher risks (Zhang et al., 2011). The means of purchasing online is extremely diverse than traditional as it has exposed to increased vulnerability of perception towards imbalance in online shopping. Different problems can be faced by consumer such as receiving wrong product or low-quality product, late or no delivery even the payment is clear and such others. This depicts that in online shopping there is less trust and more risks than physical stores as it is complex to determine the security, product, issues related to privacy in the process of purchasing (Kamalul Ariffin et al., 2018). 
In developed countries, trends related to online shopping are at the stage of maturity, while, in developing countries it is increasing rapidly such as in Pakistan (Ahmed \& Akhlaq, 2015). The acceptance of online shopping in Pakistan is extremely challenging as most of the time individuals do not trust on companies when it comes to purchase online (Ahmed \& Akhlaq, 2015). However, flexibility is shown by young generation especially in terms of ordering food. In Pakistan, people also focus on purchasing hardware things and clothes. Within Pakistan, online shopping is low because of unavailability of internet, high computer cost, high level of cybercrimes or frauds, and others (Ahmed \& Akhlaq, 2015; Goldsmith \& Goldsmith, 2002). With the increasing acceptance of internet devices such as mobile phones and laptops, the attention of people has transferred towards the use of online platforms such as websites to purchase products.

With respect to purchasing online, the perceived risk of customers' is a crucial issue for research as it has direct impact on their attitude towards online purchases. Perceived risks in e-commerce or purchasing online has negative impact on the online purchase intention as consumers feel some risk they would have to face when shopping through internet (Almousa, 2011). It is noticed that perceived risks towards online shopping are not determined completely making it essential to evaluate the risks that are impacting retailers when dealing with customers online. This makes it necessary to determine the risks that have significant impact on purchasing intention of consumers. The purpose of the study is to analyze the impact of perceived risks on the consumers online purchase intention in order to provide an idea to online retailers about the risks that needs consideration in targeting consumers for online purchase.

Some of the precedent studies (Masoud, 2013; Mathur, 2015) only focused on limited number of perceived risk and suggested to focus on more types of risks. They are also generalized determining overall impact of risks on online purchase intention (Ariff et al., 2014). Since, each of the industry has different response for online shopping it is effective to evaluate the impact of the perceived risks on online purchase intention of consumers industry wide. This study is focused on evaluating the relationship between 6 kinds of perceived shopper risks and consumers online purchase intention. The 6 risk factors are product risk, financial risk, security risk, social, and time risk, which have impact on the online purchase intentions. It is noticed that the precedent studies have focused on impact of perceived risk on online shopping generally and have not been segregated it 
industry wide to determine the types of risks dominant in each industry. Therefore, in this research study, the apparel industry has been focused and the impact of consumers' perceived risk on online purchase intention of branded apparels in Pakistan is emphasized.

\section{Statement of the Problem}

The acceptance of online shopping in Pakistan is extremely challenging. The trend is changing with increasing acceptable of devices such as mobile phones and laptops. The perceived risk of customers' is a crucial issue for research. It has negative impact on the online purchase intention as the problem statement is:

"Perceived consumer risks negatively influence the online purchase intention of consumers buying branded apparels"

\section{RESEARCH QUESTIONS}

- Why customer prefer online shopping?

- How perceived risk of online shopping can be reduced?

- What is the impact of perceived risk on online purchase intention of consumer's within apparel industry?

\section{OBJECTIVES OF THE STUDY}

This study aims to evaluate the impact of perceived risk on online purchase intention of consumer's within apparel industry. Thus, objectives of our study are:

(1) To review the past literature on the constructs taken for the study.

(2) To empirically test the role of shopping orientation, prior online purchase experience, online trust on the customer online purchase intention among audience.

(3) To empirically test the influences of demographics on customer online purchase intention among audience

This paper aims to examine the relationship between six factors of consumers' perceived risk and consumers' online purchase intentions. In particular, this study will examine the relationship 
between financial risk, product risk, security risk, time risk, social risk and psychological risk and online purchase intention.

\section{LITERATURE REVIEW}

The theory of planned behavior (TPB) was proposed by Icek Ajzen with the intention to develop further the power of theory of reasoned action by incorporating the concept of perceived behavioral control (Meskaran et al., 2013). The TPB focuses on associating individuals' behavior and belief along with additional construct of behavioral control along with attitude and subjective norms. It includes perceived behavioral control in addition to behavior as factor that persuades intention. Many of the studies (George, 2004; Redda, 2019) that involve aspect of online shopping made use of TPB to comprehend and evaluate the behavior of people towards shopping online. Since this study involves assessing the perception of consumers regarding perceived risk in online purchasing, this theory has been focused and the hypothesis are derived based on the relationships defined by theory of planned behavior.

\section{Online Purchase Intention}

Among all the activities that are prominent on internet, the most important or vital is online shopping which is being followed by web surfing and email (Jamali et al., 2014). It is defined it as the readiness of customer to purchase products over the internet (Meskaran et al., 2013). Their readiness to buy product or service from any online store is regarded as online purchase intention. (Close \& Kukar-Kinney, 2010) defined online purchase intention as the willingness of customer to use service of internet for actually purchasing the product or service or for comparing product prices. Purchase intention of customers is important in determining consumer behavior which is dependent on different influencing factors making measurement complex under various circumstances (Kamalul Ariffin et al., 2018). Presence of security statements and strong privacy is not the means of increasing online purchase intention (Bhatti et al., 2018). It was determined that customer trust on the ability of the organization to fulfill their wants and needs is more important than trusting in goodwill to impact purchase intention.

A measure that can be used for determining actual activities of consumers buying is regarded as purchase intention(Close \& Kukar-Kinney, 2010). From precedent studies (Kamalul Ariffin et al., 2018; Meskaran et al., 2013; Popli \& Dr. Mishra, 2015) it has been determined that perceive risk 
in the context of customers have negative impact on the online purchase intention for apparels. The higher the risk perception the more it discourage consumers' purchasing intention. The effect of six diverse perceived risks including financial, time, information security, product and delivery on online shopping intention in Jordan is assessed in a study by utilizing sample of around 395 consumers who shop online. The results indicated that product risk, financial risk, delivery risk, and information security risk have negative impact on online shopping intentions (Masoud, 2013). Online purchasing and selling is the new platform, significant changes are required to be done to enhance or gain the customers trust and for this to happen, customers need to recognize that they can obtain a better offer in purchasing online than to shop from any physical outlet (Azizi \& Javidani, 2014; Forsythe \& Shi, 2003). It is concluded that businesses must be aware of these risks and strategies that can be used for overcoming these issues. If there is less perceived risk, the online shopping experience of consumers will become positive which would lead to increase in online purchase intention.

\section{Perceived Risk}

This is defined as losses expectation which means that the larger the expectation, the higher are the chances that consumers risk will perceive (Schierz et al., 2010). It is defined as the perception of consumers on contrary and changeable results of purchasing a service or product (Ko et al., 2004). There are two elements in the concept, consequences and indecisions. Consequences are regarded as the significance of losses and indecisiveness is probability of unfavorable results. Perceived risk plays vital role in identifying purchase intention of consumers as their perception towards risk contributes in evaluating their behaviors and attitude for purchasing (Kamalul Ariffin et al., 2018). They perceive high risk level at buying online in comparison to the physical stores. Consumers who have high perceived risk would not prefer purchasing products or services online. This depicts that perceived risks have negative impact on the consumers online purchase intention (Almousa, 2014).

It is noticed that the higher the perceived risk of purchasing by online retailers, the customers purchase intention is weaker towards online retailer (Kim \& Lennon, 2013). There is negative impact of perceived risk on the intentions of customers for purchasing online (Ahmed \& Akhlaq, 2015). This demonstrates that intention of customers to buy products online is suppressed when 
they find that there is high risk involved in the transaction. Perceived risk comprises of different factors which includes safety, performance, social, financial, psychological, and time risk (Featherman \& Pavlou, 2003). Some additional six dimensions are also identified which comprises of financial, social, performance, physical, psychological, and time risks (Ko et al., 2004). Different studies (Almousa, 2014; Kim \& Lennon, 2013) have determined the impact of various perceived risks on the purchase intention that is online. Considering this, in this research five different factors are considered that includes product risk, financial risk, security risk, time risk, and social risk that influence customers online purchase intentions.

\section{Product Risk and Online Purchase Intention}

Risk in online shopping is not associated to product risk only but also with the point and channel of purchase (Masoud, 2013). Product risk is the risk if the product unable to meet the customers' expectations (Peter \& Ryan, 1976). The risk associated with the product is performance is very higher as customer cannot judge and completely determine the quality of the product before purchasing the product online (Korgaonkar \& Karson, 2007). Customer faces the higher amount of risk when purchasing the apparels online than to purchase from any physical outlet (Goldsmith $\&$ Goldsmith, 2002). Screen and softwares of the system are not sufficient enough to show the attributes of the product and that leads towards the uncertainty in internet shopping. It becomes extremely tough for the people to judge the quality of the product at the time of ordering (Forsythe \& Shi, 2003). It is the risk which is related to making the poor purchasing decision, inability of returning the product, or not receiving the product you paid for or the product is unable to meet your demands and expectations or product is underperforming (Bhatnagar \& Ghose, 2004). Customer always perceives a higher level of risk in online purchasing rather than purchasing from physical outlet because of not touching the product (Ariff et al., 2014).

One of the major restriction that limits customer in buying product online is little or no possibility to physically check the product and there is high level of dependency of the individual on the information that seller has provided (Popli \& Dr. Mishra, 2015). This leads to high level of buying risk in the mind of consumers and there are chances that it might fail to reach expectations. A study highlighted that around $82 \%$ of customers leave their online shopping incomplete because of limited information, lack of assistance, or poor features of website (Bhatti et al., 2018). For 
example, when the customer compares delivered and displayed products in terms of shape, color, or outlook and it is out of the customers' abilities and reach to assess and check the product qualities, it increases their level of perceived product risk (Dai et al., 2014). The confidence and online purchase intention of customers are reduced based on product risks existence. The inability of feeling, touching, and testing the product are the main concerns for customers when buying online which leads to increase in product risk (Bhatti et al., 2018). Many of the customers are mostly concerned about the quality of product and this concern restricts them from making online purchases. However, it also has significant impact on the behavior of customers in terms of buying online. Consumers perceived product risk when the product price is high, and information is limited. The precedent studies have determined the fact that there is negative influence of product risk on the online purchase intention of consumers' (Ariff et al., 2014). Based on this, H1 is as follows:

H1: Product risk negatively influence consumers'online purchase intention for branded apparels.

\section{Financial Risk and Online Purchase Intention}

It refers to the potential loss a customer may faces as a result of transaction (Peter \& Ryan, 1976). Customer do not think providing their credit card details is the safe step to be taken and don't think it is secured enough (Forsythe \& Shi, 2003). They have a fear of credit card fraud, customer do not tend to provide their card details during online shopping, customer do not want to give the credit card details if there is huge amount of discount offer, customer fear that platform of ecommerce are secured enough to be provide the credit card details, customer have doubts on the good will of the online store(Gerber et al., 2014).

Consumers are worried while shopping online about their credit cards and personal information. Many of them prefer cash on delivery when purchasing online instead of making payment through bank transfers or using cards (Ariff et al., 2014). Apart from this, consumers are also concerned that e-commerce websites are not secure and can use their personal information negatively. Fear of fraud using credit cards is one of the major risk that is involved with consumers purchasing online (Gerber et al., 2014). This risk is defined as the probability that online consumer might suffer from monetary or deduction of hidden charges due to purchase made for the product online (Kamalul Ariffin et al., 2018). This risk involves repairing cost possibility for the product along 
with maintenance charges which are mostly hidden from customers (Popli \& Dr. Mishra, 2015).

Financial loss and less quality product are the reasons due to which there is negative impact on consumers online purchase intention. The low level of security and increasing cybercrime makes customer worried making them resistant in purchasing any product using online platforms (Azizi \& Javidani, 2014). The purpose of sensitive products such as apparel is more risky than other products such as computer software. The inability to test and assess apparel from a virtual store increases their reluctance to online purchase (Masoud, 2013). Hence, financial risk is regarded as stronger forecaster of consumers online purchase intention for products such as apparels. Based on this, the hypothesis developed is as follows:

\section{H2: Financial risk negatively influences consumers' online purchase intention for branded apparels.}

\section{Security Risk and Online Purchase Intention}

Customers observe the value of goods through the information provided by the websites. Information includes: quality, customer service quality, delivery capability (Kamalul Ariffin et al., 2018). Security risk refers to potential loss because of online fraud, hacking which exposes the privacy of online users (Heirsh Soltanpanah, 2012). Security risk means as disclosing the account number, or credit or debit card number or pincode of the online user. Thus online platform provides the easy way for purchasing, but absence of security mechanism badly affects the intentions of the customer to purchase online (Meskaran et al., 2013).

Customer do not feel satisfied in providing their credit card number or shipping information in online purchase transaction as they don't think that the platform is secured (Martín \& Camarero, 2008; Masoud, 2013). However more details are required when customer are shopping apparels online (Dai et al., 2014).Security risk is having negative impact in online purchasing of apparels. When people aren't confident with the website, they do not tend to give you their real information, they come up with providing false information or incomplete information (Kamalul Ariffin et al., 2018). Most people do not prefer to purchase the products online due to prevalence of inconvenience but because of higher chances to misuse their credit card information by others (San Martín \& Camarero, 2009). The relationship between online purchase intention and security risk 
is significant (Teo \& Liu, 2007). Based on this, the $\mathrm{H} 3$ is developed as follows:

\section{H3: Security risk negatively influences consumers' online purchase intention for branded apparels.}

\section{Social Risk and Online Purchase Intention}

Social risk refers that the product received by the customer may result in family disapproval (Dowling \& Staelin, 1994). This risk is also known as the status loss within the social group due to the disapproval by people because of the use of online platform (Gerber et al., 2014; Kaplan et al., 1974; Peter \& Ryan, 1976). Social risk refers to the feeling of fear and worry from family members or friends who disapprove purchasing online (Popli \& Dr. Mishra, 2015). The customer may avoid purchasing online because of disapproval from friends and family members as their disapproval plays a significant role to discourage customer in decision making of online purchase (Zhang et al., 2011). Social risk is one of the greatest factors that influences the consumers online purchasing (SHIH-MING PI AND JIRAPA SANGRUANG, 2011).

This risk is insignificant on customer internet shopping intention (Kamalul Ariffin et al., 2018). Product received may result in disapproval by friends and family (Li \& Zhang, 2002). It also reflects to the dissatisfaction that an individual faces from family and friends due to in effective selection of the product by him (Ueltschy, 2010). This risk is known as the likelihood that the buying of the product might lead to the thinking about customer as unfavorable in the mind of others (Kaplan et al., 1974). Customers will be negatively judged and evaluated due to selection of brand and preferences (Semeijn et al., 2004). This risk also means as the loss of credibility and reputation of an individual in his social group because of the unsustainability or inappropriateness of the product and dissatisfaction in selecting the internet as a shopping channel. Considering this, the $\mathrm{H} 4$ is as follows:

H4: Social risk negatively influences consumers' online purchase intention for branded apparels.

\section{Time Risk and Online Purchase Intention}

Customers may lose their time in finding the reliable and suitable website, placing the order, and 
they may also face delays in their order deliveries (Forsythe\& Shi, 2003). Customer think and they are interested in purchasing from the physical outlet as it is faster and easier (Forsythe \& Shi, 2003). Loss of time during online transaction, selecting the suitable website, in placing the order and waiting for the order to arrive are considered to be the time risk (Dai et al., 2014). Customer fear of the delivery being delayed, delivery won't be made in a time frame, customers have to stay and wait until the product arrives or being delivered, if the product comes earlier I might not be at my delivery address or given address (Hsiao, 2009).

One influential factor that impacts customers' behavior towards online shopping is time risk. It includes the problematic experience associated with online transactions that are due to struggle of submitting orders and delays in product delivery (Kamalul Ariffin et al., 2018). It is also regarded as the time that customers take for making their decision to purchase and to wait for their product arrival (Gerber et al., 2014). Time risk is also linked with inability to meet the expectation levels of customers and it needs to be returned for placement (Ariff et al., 2014). Consumers' believe that online shopping is a time-consuming process because customers have to search, browse, buy and wait for the arrival of product (Hsiao, 2009; Popli \& Dr. Mishra, 2015). The time that is wasted in searching for the product online or on website and then comparing it with other makes customers frustrated because many of the people do not know how to find the right product online(Gerber et al., 2014; Meskaran et al., 2013; Zhang et al., 2011).

The problem of in-depth indulgence and requiring a lot of time to search product, know about, order, and waiting for its delivery makes consumers reluctant in making purchase online. In the case of apparels, time risk is high because consumers take a lot of time to search the required product and compare it with competitors before making purchase(Hsu, 2012; Kamalul Ariffin et al., 2018). The involvement of high level of time makes it difficult for consumers to make decision regarding purchasing the product online. It deters their decision to purchase product online as it requires a lot of time to find a suitable website or product(Gerber et al., 2014; Masoud, 2013). Based on this, the $\mathrm{H} 5$ is developed as follows:

H5: Time risk negatively influences consumers' online purchase intention for branded apparels. 


\section{CONCEPTUAL FRAMEWORK}

Based on the previous studies a conceptual framework is established shown in Figure 1 below. The following sections discusses both dependent and independent variables. At first dependent variable, online purchase intention is discussed which is then followed by the discussion of independent variables highlighted in the conceptual framework.

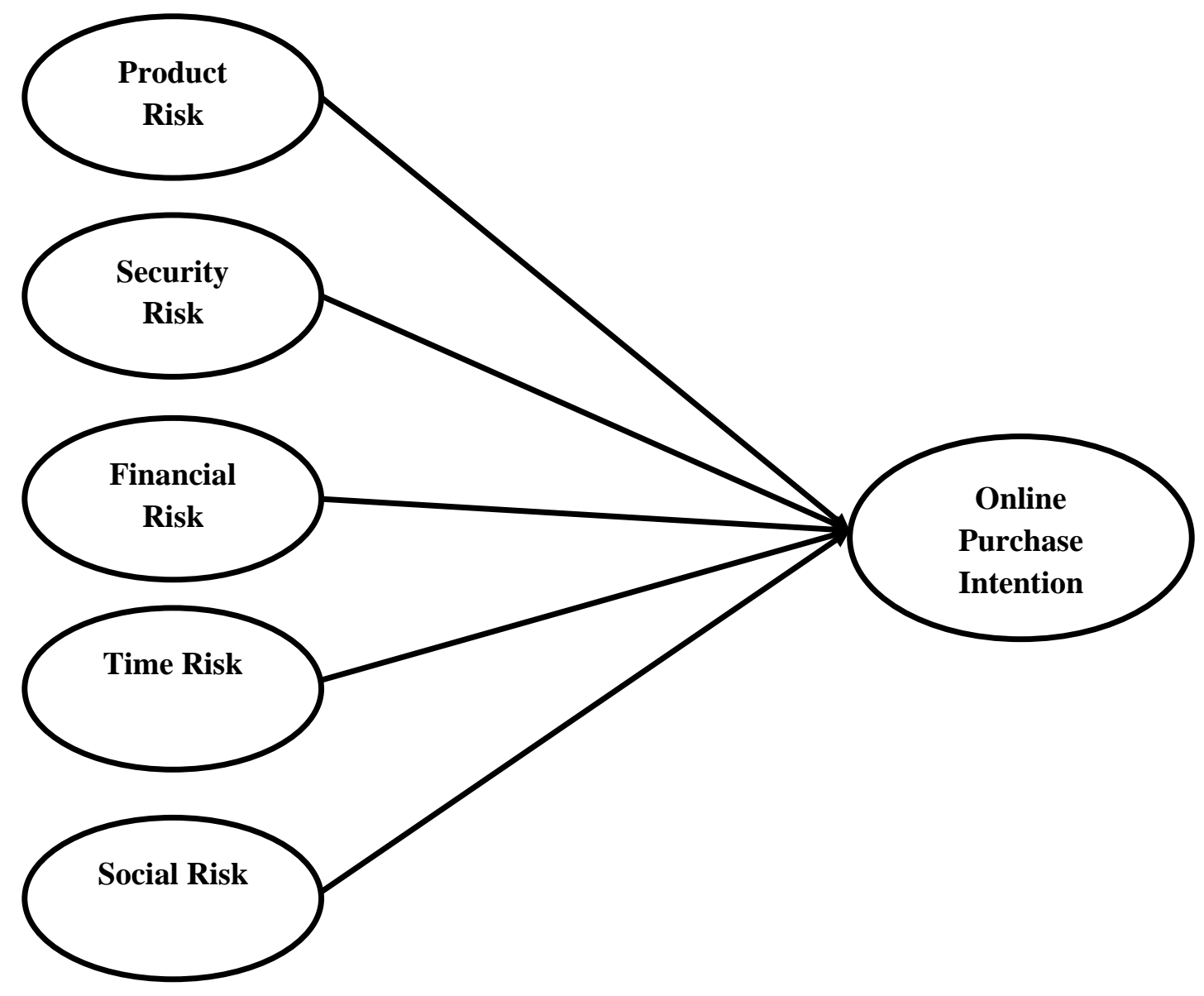

Figure 1: Conceptual Framework

\section{RESEARCH METHODOLOGY}

\section{Procedure}

The procedure adopted by this study is quantitative as it involves testing hypothesis. Quantitative method comprises of objective measurements along with statistical, numerical, and mathematical 
analysis of data collected through surveys, questionnaires, and polls. As the study involved data collecting through questionnaire, quantitative method is regarded as the appropriate procedure to conduct this study and to develop findings.

\section{Sample Size and Population}

The population of the research study is those individual $82 \%$ of consumers who have internet access and made purchase online. The sample size is 20. Online shoppers or consumers who made purchase online are selected as population because this study aims to determine the impact of perceived risk on online purchase intention of consumers buying branded apparels. Thus, convenience sampling has been used in the study as it enables the researcher to select respondents as per their convenience and ease. It is ensured that the sample represent the subset of selected population.

\section{Scale and Measure}

Within the considered research, all the constructs are taken from a study related to the research topic and is earlier developed. The constructs used in the study are product risk (5 items), security risk (5 items), financial risk ( 5 items), time risk (4 items), social risk (4 items), and online purchase intention (5 items). In total, there were 37 items in the questionnaire including demographics from which 32 items were representing the selected constructs. The scale that is used for getting the questionnaire filled is 5-point Likert Scale ranging from strongly agree to strongly disagree.

\section{Data Collection}

This study involved gathering primary data in order to understand the perspective of consumers with respect to online shopping for branded apparel. In the process of collecting primary data, this research conducted online survey so that the targeted sample can be reached easily. The advantage of collecting primary data is that it provides relevant information required to test the established hypothesis from the real-world perspective. The collection of primary data helped in understanding the perspective of customers about online purchase and the influence of perceived risk on their online buying behavior. 


\section{Data Analysis}

The data collection in the study is analyzed using quantitative data analysis technique. Some statistical tests are performed on SPSS in order to generate results and to determine whether the hypothesis are rejected or failed to reject. The tests that are conducted to evaluate the constructs and its items are descriptive statistics, correlation analysis, reliability analysis.

\section{RESULTS}

\section{Profile of the Respondents}

We have conducted our research on a sample size of 200 respondents out of which $50 \%$ were females while $50 \%$ were males. Majority of the respondents belonged to the age group of 20-25 (47\%). In term of profession, $53 \%$ were full time employee, $6 \%$ were part time employee, $7 \%$ were doing internship, $18 \%$ were students while $14 \%$ were housewives or unemployed. All of them were with different income level, $18 \%$ of them earn 15-000 to 25000, (17\%) Rs.25000$35000,35,000-45,000$ (11\%), while 7\% of them earn 45,000-50,000, 24 people did not share their income level or they don't earn and rest of them earn more than Rs.50, 000. As far as their opinions are concerned, $51 \%$ of the respondents prefer shopping online, $29 \%$ of them have also shopped online earlier but do not prefer this channel while $20 \%$ of the respondents were neutral.

\section{Correlation Analysis}

Correlation analysis was conducted to determine the issue of multi-co linearity and to ensure that variables and distinct and unique (Bryman, 2004). The product risk has strong relationship with financial risk. However, it has weak relationship with security risk, social risk, and time risk. However, it has negatively very weak relationship with online purchase intention. Financial risk has positive and strong relationship with security risk and time risk with $r$ value greater than 0.5. It has positive and weak relationship with social risk. However, it has negative and very weak relationship with online purchase intention. Furthermore, Security risk has positive and weak relationship with social and time risk. It has negative and very weak relationship with online purchase intention. Social risk has positive and weak relationship with time risk. It has positive and very weak relationship with online purchase intention. Lastly, the time risk has positive and weak relationship with all the variables except of financial risk as it has strong relationship. Lastly, it has negative and very weak relationship with online purchase intention. 


\section{Construct Validity}

In order to determine the validity of all the construct of research, two approaches has been considered which are convergent and discriminant (Bryman, 2004).

\section{Discriminant Validity}

Discriminant analysis is used for determining whether the constructs of the study are distinct and unique. It is noticed that the square root of variance explain is greater than the correlation of all the constructs indicating that the constructs used in the study are distinct and unique (Fornell \& Larcker, 2012).

\section{Regression Model Test}

For the purpose of rejecting the hypothesis or failing to reject the hypothesis, regression analysis has been conducted to determine the impact of each independent variable (perceived risk) on dependent variable (OPI).

Security Risk. For testing the hypothesis "Security risk negatively influences consumers' online purchase intention for branded apparels

\begin{tabular}{cccccc}
\hline & $\begin{array}{c}\text { Un standardized } \\
\text { Coefficients }\end{array}$ & & $\begin{array}{c}\text { Standardized } \\
\text { Coefficients }\end{array}$ & & \\
Variable & $\mathrm{B}$ & Std. Error & Beta & $\mathrm{T}$ & Sig. \\
\hline (Constant) & 2.822 & .210 & & 13.415 & .000 \\
SR & -.025 & .079 & -.022 & -.312 & .755 \\
\hline
\end{tabular}

a. Dependent Variable: OPI

The significance value is greater than 0.05 due to which the above hypothesis is rejected indicating that there is no negative influence of security risk on online purchase intention of consumers' buying branded apparels.

Product Risk. The hypothesis "Product risk negatively influences consumers' online purchase intention for branded apparels" is tested by conducting simple regression.

Regression Result (PR)

\begin{tabular}{cccccc}
\hline & \multicolumn{2}{c}{$\begin{array}{c}\text { Un standardized } \\
\text { Coefficients }\end{array}$} & $\begin{array}{c}\text { Standardized } \\
\text { Coefficients }\end{array}$ & & \\
\cline { 2 - 4 } Variable & B & Std. Error & Beta & T & Sig. \\
\hline
\end{tabular}


Journal of Marketing Strategies, Volume 1, Issue 1, 2019

\begin{tabular}{llllll}
\hline (Constant) & 3.325 & .190 & & 17.475 & .000 \\
PR & -.237 & .076 & -.216 & -3.124 & .002 \\
\hline
\end{tabular}

a. Dependent Variable: $O P I$

The significance value is less than 0.05 which means that the hypothesis is failed to reject indicating the fact that product risk negatively influences online purchase intention of consumers' buying branded apparels.

Financial Risk. The simple regress is conducted to test the hypothesis "Financial risk negatively influences consumers' online purchase intention for branded apparels".

Regression Result (FR)

\begin{tabular}{|c|c|c|c|c|c|}
\hline \multirow[b]{2}{*}{ Variable } & \multicolumn{2}{|c|}{$\begin{array}{c}\text { Un standardized } \\
\text { Coefficients }\end{array}$} & \multirow{2}{*}{$\begin{array}{c}\begin{array}{c}\text { Standardized } \\
\text { Coefficients }\end{array} \\
\text { Beta }\end{array}$} & \multirow[b]{2}{*}{$\mathrm{T}$} & \multirow[b]{2}{*}{ Sig. } \\
\hline & B & Std. Error & & & \\
\hline (Constant) & 3.368 & .214 & & 15.724 & .000 \\
\hline FR & -.233 & .079 & -.204 & -2.954 & .004 \\
\hline
\end{tabular}

a. Dependent Variable: OPI

The significance value of the construct is less than 0.05 due to which the hypothesis is failed to reject. This means that financial risk negatively influences online purchase intention of consumers for branded apparels.

Social Risk. The simple regression analysis is done to test the hypothesis "Social risk negatively influences consumers' online purchase intention for branded apparels".

Regression Result (SocR)

\begin{tabular}{|c|c|c|c|c|c|c|}
\hline \multirow{2}{*}{\multicolumn{2}{|c|}{ Model }} & \multicolumn{2}{|c|}{$\begin{array}{l}\text { Un standardized } \\
\text { Coefficients }\end{array}$} & $\begin{array}{l}\text { Standardized } \\
\text { Coefficients }\end{array}$ & \multirow[b]{2}{*}{$\mathrm{T}$} & \multirow[b]{2}{*}{ Sig. } \\
\hline & & $\mathrm{B}$ & Std. Error & Beta & & \\
\hline \multirow[t]{2}{*}{1} & (Constant) & 2.206 & .229 & & 9.619 & .000 \\
\hline & SocR & .186 & .075 & .174 & 2.496 & .013 \\
\hline
\end{tabular}

a. Dependent Variable: $O P I$

The significance value is greater than 0.05 due to which the hypothesis is rejected. This means that social risk does not have negative influence on online purchase intention of consumer's for branded apparels. 
Time Risk. The simple regression analysis is done to test the hypothesis "Time risk negatively influences consumers' online purchase intention for branded apparels".

Regression Result (TR)

\begin{tabular}{|c|c|c|c|c|c|}
\hline \multirow[b]{2}{*}{ Variable } & \multicolumn{2}{|c|}{$\begin{array}{c}\text { Un standardized } \\
\text { Coefficients }\end{array}$} & \multirow{2}{*}{$\begin{array}{c}\text { Standardized } \\
\text { Coefficients } \\
\text { Beta }\end{array}$} & \multirow[b]{2}{*}{$\mathrm{T}$} & \multirow[b]{2}{*}{ Sig. } \\
\hline & B & Std. Error & & & \\
\hline (Constant) & 3.033 & .192 & & 15.769 & .000 \\
\hline TR & -.102 & .068 & -.105 & -1.498 & .136 \\
\hline
\end{tabular}

a. Dependent Variable: OPI

The significance value is greater than 0.05 which means that the hypothesis is rejected indicating that time risk does not have negative influence on customers online purchase for branded apparels.

\section{DISCUSSION AND CONCLUSION}

This research study is aimed at determining risk factors related to perceived risk of consumers that have impact on the online buying intention towards branded apparels. For this purpose, it made use of perceived risks such as financial risk, security risk, product risk, time risk, and social risk. The perceived risk factors are hypothesized to have significant and negative influence on consumers' online purchase intention. The results generated of the current research showed that only two factors which are product risk and financial risk have significant and negative impact on consumers online purchase intention for branded apparels. While on the other hand, security risk, time risk, and social risk factors are insignificant.

The results related to hypothesis 1 shows that product risk has negative influence on consumers online purchase intention towards branded apparels which is in line with previous research. Product risk is defined as the failure to meet the expectation or desire of customers (Kamalul Ariffin et al., 2018). Customers do not have the opportunity to check product physically and is totally dependent on the information shared by seller. By purchasing online, customers do not receive the expected or desired product or quality of product. Their inabilities to check, test, and touch the product are the main concern when purchasing online (Bhatti et al., 2018; Dai et al., 2014). This has been supported with the result of this study as the hypothesis has been failed to reject which means that there is perceived product risk for consumers when they are purchasing 
branded apparels online. Product quality and probability to not getting the demanded apparel restricts them from purchasing branded apparels online. These reasons indicate that customers online purchase intention for branded apparels is easily perceived by product risk.

The results related to hypothesis 2 is in connection with the previous study by Kamalul Ariffin et al. (2018) indicating that financial risk is an aspect due to which customers intention to shop online branded apparels is restricted and it plays vital role in determining online purchase intention. Financial risk has wide level of impact for goods purchase online (Azizi \& Javidani, 2014). Findings indicated that all the elements related to this risk are the means of negative association with online purchase intention. Customers mostly spend more money when they are purchasing online from a website that offers promotions and discounts. The illusion of discounts leads customers to overspend. Based on this, it has been determined that customer's purchase intention to shop online branded apparels is easily perceived by financial risk.

The results related to hypothesis 3 is contrary to the research conducted by previous scholar which stated that security risk has negative relationship with online purchase intention (Kamalul Ariffin et al., 2018). The findings of the study indicated that security risk is not associated with online purchase intention. Customers do not feel that their information related to debit or credit card is not secured. They do not feel that the website is not secure, or their personal information will be passed on to other companies. Consumers do not fear that won't be able to access information of the online shopping company in case of any issue. They believe that the platform is secured, and they can provide their shipping information or credit card information on the website. Hence, based on this, it has been determined that customer's online purchase intention to shop online for branded apparels is not easily perceived by security risk.

The results related to hypothesis 4 is in association with precedent study which showed that social risk has negative relationship with online purchase intention of customers (Kamalul Ariffin et al., 2018). The result indicated that this risk has no association with online purchase intention. They would not be assessed negatively for their product or brand selection. It means that the online shopping would not result in disapproval by family because it is the customer's personal decision to buy online. Moreover, it also does not reveal the character or image of any person buying online 
because it is now becoming a norm and many people are now preferring to purchase online branded apparels. It also does not need recognition by friend or family because the intention to shop online is based on the individual taste and preferences. It would also not reduce customer's evaluation or value in front of others. Based on this, it can be stated that customers online purchase intention to shop online branded apparels is not perceived by social risk.

At last, the results related to $\mathrm{H} 5$ is in contradiction to previous study which stated that time risk has negative relationship with consumers purchase intention to buy branded apparels online (Kamalul Ariffin et al., 2018; Zhang et al., 2011). The finding of the current study indicates that customers do not waste a lot of time buying online but they find is effective and time saving. For them buying product online is not waste of time as technological advancements has lead to proper search engine optimization making it easier for them to search and purchase the desired apparel easily. Moreover, they are also not impatient for wait for the product arrival as the product reaches their address in the expected time. The consumers do not find time as the factor that hinders them in making online purchase. They are satisfied with the time it takes them to make purchase and for the product to arrive as they think that this process has been made effective. Based on this, it has been determined that customer's online purchase intention to shop braded apparels is not perceived by time risk.

It is concluded that there are different perceived risks that have varying impact on the online purchase intention of customers who are focusing on buying branded apparels. The perceived risks discussed in this research study are product risk, financial risk, security risk, time risk, and social risk. The influence of these factors on online purchase intention of customers for branded apparel has been evaluated in this study by conducting survey from the selected sample. The questionnaire is developed in which 6 constructs are used each of which has particular items. The questionnaire is filled using 5-point Likert scale. The results of these tests are used to develop findings and discussion for the study.

The findings and discussion of the research study has shown that financial risk and product risk have negative and significant influence on the dependent variable that is online purchase intention. The consumers' intention to purchase branded apparels online is easily perceived by these two 
risks. The customers do not prefer to shop branded apparels online due to presence of these two risks as they believe that they might not be able to test and check the product physically which restricts them. Moreover, they also tend to spend more when purchasing online due to availability of promotions and discounts. However, social risk, time risk, and security risk do not negatively influence their intention to shop for branded apparels online. They do not believe that the presence of these risks are significant and can have massive impact on them. Based on this, it has been concluded that among all the perceived risks, product risk and financial risk negatively and significantly influence customers online purchase intention towards branded apparel. They are reluctant to purchase apparels online due to their inability to check or feel the apparel physically and the chance of overspending due to promotions and discounts on the website.

\section{RESEARCH IMPLICATIONS}

The study has different practical implications. The first is that it can be used by online retailers under they can consider the concerns of customers with respect to perceived risk. They can provide information about their product on the website and make a customer support agent available online all the time to answer the questions of people with respect to product and security risk. The apparel brands such as Sana Safinaz, Outfitter, Junaid Jamshed, and many others can state on their website about the security systems that are being used by them to protect the information of customers. They can reduce financial risk by offering warranty and guarantee for the products purchased online which would increase the online purchase by customers.

In order to reduce product risk, they can either make all the information available on their website and they can also offer people the ability to place order easily, check the product on arrival, and make payment they are satisfied with the product received and its quality. These techniques would help online retailers to deal with perceived risks that are prominent in the process of online shopping and impact customer's intention to buy products online. Moreover, the retailers can also understand the importance of online shopping for customers as they would have complete information about their perspective regarding buying products online. This would provide clear idea to them about how to minimize the risk and to attract consumers to make buying online as significant part of their process. 


\section{LIMITATIONS AND FUTURE RESEARCH}

The current study focused on evaluating the impact of 6 factors of perceived risk on consumers online purchase intention in Pakistan. The future studies can enhance their scope by targeting people outside Pakistan to determine the extent to which these risks influence them with respect to buying online. Apart from this, the future studies must also focus on other industries apart from apparel to understand the involvement of perceived risk and its influence on the online purchase intention of customers. This could be done to understand the difference in the perceived risk based on the industry or type of products being purchased by customers. Moreover, this study did not consider any mediating or moderating factor with respect to influence of perceived risk and online apparel purchase intention. Future studies can include the mediating factor of trust, attitude, and behavior as well as moderating factors such as personality, past experiences, and professional conduct. 


\section{REFERENCES}

Ahmed, E., \& Akhlaq, A. (2015). Digital commerce in emerging economies: Factors associated with online shopping intentions in Pakistan. International Journal of Emerging Markets, 10(4), 634-647. https://doi.org/10.1108/IJoEM-01-2014-0051

Almousa, M. (2011). Percieved risk in apparel online shopping. Jornal of Canadian Social Science, 7(2), 23-31.

Almousa, M. (2014). The Influence of Risk Perception in Online Purchasing Behavior: Examination of an Early-Stage Online Market. International Review of Management and Business Research, 3(2), 779-787.

Ansari, J., Khalid, F., Jalees, D. T., \& Ramish, M. S. (2017). Consumer's Attitude towards Ramadan Advertising. South Asian Journal of Management Sciences, 11(1), 15-31. https://doi.org/10.21621/sajms.2017111.02

Ariff, M. S. M., Sylvester, M., Zakuan, N., Ismail, K., \& Ali, K. M. (2014). Consumer perceived risk, attitude and online shopping behaviour; Empirical evidence from Malaysia. IOP Conference Series: Materials Science and Engineering, 58(1). https://doi.org/10.1088/1757$899 \mathrm{X} / 58 / 1 / 012007$

Azizi, S., \& Javidani, M. (2014). Measuring e-shopping intention: An Iranian perspective Measuring e-shopping intention: An Iranian perspective. September.

Bhatnagar, A., \& Ghose, S. (2004). Segmenting consumers based on the benefits and risks of Internet shopping. Journal of Business Research, 57(12 SPEC.ISS.), 1352-1360. https://doi.org/10.1016/S0148-2963(03)00067-5

Bhatti, A., Saad, S., \& Gbadebo, S. (2018). Convenience Risk, Product Risk, and Perceived Risk Influence on Online Shopping: Moderating Effect of Attitude. International Journal of Business Management, 3(2), 1-11.

Bryman, A. (2004). The nature and process of social research. Social Research Method, $@$ article $\{$ bahari2010qualitative, title $=\{$ Qualitative versus quantitative research strategies: contrasting epistemological and ontological assumptions $\}$, author $=\{$ Bahari, Siti Fatimah $\}$, journal $=\{$ Sains Humanika $\}$, volume $=\{52\}$, number $=\{1\}$, year $=\{2010\}\} @$ article $\{b, 3-16$.

Close, A. G., \& Kukar-Kinney, M. (2010). Beyond buying: Motivations behind consumers' online shopping cart use. Journal of Business Research, 63(9-10), 986-992. https://doi.org/10.1016/j.jbusres.2009.01.022

Dai, B., Forsythe, S., \& Kwon, W. (2014). The Impact of Online Shopping Experience on Risk Perceptions and Online Purchase Intentions: The Moderating Role of Product Category and Gender. Journal of Electronic Commerce Research, 15(1), 13-24. 
Dowling, G. R., \& Staelin, R. (1994). A Model of Perceived Risk and Intended Risk-Handling Activity. Journal of Consumer Research, 21(1), 119. https://doi.org/10.1086/209386

Featherman, M. S., \& Pavlou, P. A. (2003). Predicting e-services adoption: A perceived risk facets perspective. International Journal of Human Computer Studies, 59(4), 451-474. https://doi.org/10.1016/S1071-5819(03)00111-3

Forsythe, S. M., \& Shi, B. (2003). Consumer patronage and risk perceptions in Internet shopping. Journal of Business Research, 56(11), 867-875. https://doi.org/10.1016/S01482963(01)00273-9

George, J. F. (2004). The theory of planned behavior and Internet purchasing. Internet Research, 14(3), 198-212. https://doi.org/10.1108/10662240410542634

Gerber, C., Ward, S., \& Goedhals-Gerber, L. (2014). The impact of perceived risk on on-line purchase behaviour. Risk Governance and Control: Financial Markets and Institutions, 4(4CONTINUED1), 99-106. https://doi.org/10.22495/rgcv4i4c1art4

Goldsmith, R. E., \& Goldsmith, E. B. (2002). Buying apparel over the Internet. Journal of Product \& Brand Management, 11(2), 89-102. https://doi.org/10.1108/10610420210423464

Hair, J. F., Celsi, M., Money, A., Samouel, P., \& Page, M. (2015). The essentials of business research methods: Third Edition. The Essentials of Business Research Methods: Third Edition, 1-494. https://doi.org/10.4324/9781315716862

Heirsh Soltanpanah. (2012). A review of the literature of perceived risk and identifying its various facets in e- commerce by customers: Focusing on developing countries. African Journal of Business Management, 6(8), 2888-2896. https://doi.org/10.5897/ajbm11.1409

Hsiao, M. H. (2009). Shopping mode choice: Physical store shopping versus e-shopping. Transportation Research Part E: Logistics and Transportation Review, 45(1), 86-95. https://doi.org/10.1016/j.tre.2008.06.002

Hsu, S.-H. (2012). Factors Influencing on Online Shopping Attitude and Intention of Mongolian Consumers. The Journal of International Management Studies, 7(2), 167-176.

Jamali, K., Samadi, B., \& Marthandan, G. (2014). Prioritizing Electronic Commerce Technologies in Iranian. Interdisciplinary Journal of Contemporary Research in Business, 147-180.

Kamalul Ariffin, S., Mohan, T., \& Goh, Y. N. (2018). Influence of consumers' perceived risk on consumers' online purchase intention. Journal of Research in Interactive Marketing, 12(3), 309-327. https://doi.org/10.1108/JRIM-11-2017-0100

Kaplan, L. B., Szybillo, G. J., \& Jacoby, J. (1974). Components of perceived risk in product purchase: A cross-validation. Journal of Applied Psychology, 59(3), 287-291. https://doi.org/10.1037/h0036657 
Kim, J., \& Lennon, S. J. (2013). Effects of reputation and website quality on online consumers' emotion, perceived risk and purchase intention: Based on the stimulus-organism-response model. Journal of Research in Interactive Marketing, 7(1), 33-56. https://doi.org/10.1108/17505931311316734

Ko, H., Jung, J., Kim, J., \& Shim, S. W. (2004). Cross-Cultural Differences in Perceived Risk of Online Shopping. Journal of Interactive Advertising, 4(2), 20-29. https://doi.org/10.1080/15252019.2004.10722084

Korgaonkar, P. A., \& Karson, E. J. (2007). The influence of perceived product risk on consumers' e-tailer shopping preference. Journal of Business and Psychology, 22(1), 55-64. https://doi.org/10.1007/s10869-007-9044-y

Li, N., \& Zhang, P. (2002). Consumer online shopping attitudes and behavior: An assessment of research. Eighth Americas Conference on Information Systems, OCTOBER 2002, 508-517.

MAIGNAN, I., \& LUKAS, B. A. (1997). The Nature and Social Uses of the Internet: A Qualitative Investigation. Journal of Consumer Affairs, 31(2), 346-371. https://doi.org/10.1111/j.17456606.1997.tb00395.x

Martín, S. S., \& Camarero, C. (2008). Consumer trust to a web site: Moderating effect of attitudes toward online shopping. Cyberpsychology and Behavior, 11(5), 549-554. https://doi.org/10.1089/cpb.2007.0097

Masoud, E. Y. (2013). The Effect of Perceived Risk on Online Shopping in Jordan. 5(6), 76-88.

Mathur, N. (2015). Perceived Risks towards Online Shopping. International Journal of Engineering Development and Research, 3(2), 2321-9939. https://www.ijedr.org/papers/IJEDR1502056.pdf

Meskaran, F., Ismail, Z., \& Shanmugam, B. (2013). Online Purchase Intention: Effects of Trust and Security Perception. Australian Journal of Basic and Applied Sciences, 7(6), 307-315.

Peter, J. P., \& Ryan, M. J. (1976). An Investigation of Perceived Risk at the Brand Level. Journal of Marketing Research, 13(2), 184. https://doi.org/10.2307/3150856

Popli, A., \& Dr. Mishra, S. (2015). Factors of perceived risk affecting consumers' online purchase intention. Pacific Business Review International, 8(2), 10.

Redda, E. (2019). Attitudes towards Online Shopping: Application of the Theory of Planned Behaviour. Acta Universitatis Danubius. Economica, 15(2), 148-159.

San Martín, S., \& Camarero, C. (2009). How perceived risk affects online buying. Online Information Review, 33(4), 629-654. https://doi.org/10.1108/14684520910985657

Schierz, P. G., Schilke, O., \& Wirtz, B. W. (2010). Understanding consumer acceptance of mobile payment services: An empirical analysis. Electronic Commerce Research and Applications, 
9(3), 209-216. https://doi.org/10.1016/j.elerap.2009.07.005

Semeijn, J., van Riel, A. C. R., \& Ambrosini, A. B. (2004). Consumer evaluations of store brands: Effects of store image and product attributes. Journal of Retailing and Consumer Services, 11(4), 247-258. https://doi.org/10.1016/S0969-6989(03)00051-1

Teo, T. S. H., \& Liu, J. (2007). Consumer trust in e-commerce in the United States, Singapore and China. Omega, 35(1), 22-38. https://doi.org/10.1016/j.omega.2005.02.001

Thamizhvanan, A., \& Xavier, M. J. (2010). Determinants of customers' online purchase intention: an empirical study in India. Unit 07, 1-5.

Ueltschy, L. C. (2010). A Cross-National Study of Perceived Consumer Risk Towards Online (Internet) Purchasing. Unit 07, 1-5.

Zhang, L., Tan, W., Xu, Y., \& Tan, G. (2011). Dimensions of perceived risk and their influence on consumers' purchasing behavior in the overall process of B2C. Lecture Notes in Electrical Engineering, 111 LNEE, 1-10. https://doi.org/10.1007/978-3-642-24823-8_1 